\title{
KOLIZJA POMIĘDZY WOLNOŚCIĄ ZGROMADZEŃ RÓŻNYCH PODMIOTÓW I SPOSOBY JEJ ROZSTRZYGANIA
}

\begin{abstract}
Streszczenie. Z kolizją pomiędzy wolnością zgromadzeń różnych grup mamy do czynienia wtedy, gdy mają się odbyć dwa lub więcej antagonistyczne zgromadzenia w tym samym miejscu i czasie. Możliwe są dwa modele podejścia do tego zagadnienia: model równouprawnienia wszystkich zgromadzeń i model władczego rozstrzygania kolizji poprzez ograniczenie wolności zgromadzeń. Oba są dopuszczalne na gruncie Konstytucji RP. W polskim ustawodawstwie żaden $\mathrm{z}$ nich nie jest realizowany w pełni. W przypadku niektórych kolizji ustawodawca przewiduje możliwość ich władczego rozstrzygnięcia w oparciu o zróżnicowane kryteria. Zastosowane regulacje wydają się w niektórych wypadkach niespójne i niekonsekwentne, a w jednej sytuacji - nieproporcjonalne.
\end{abstract}

Słowa kluczowe: zgromadzenia, wolność zgromadzeń, kolizja praw podmiotowych, prawo administracyjne, bezpieczeństwo i porządek publiczny.

\section{WSTĘP}

Wolność zwoływania pokojowych zgromadzeń oraz uczestniczenia w nich to jeden z rudymentów demokracji. Mimo istnienia powszechnych wyborów publiczne zgromadzenia nie tracą na znaczeniu nawet w państwach o długich tradycjach demokratycznych, gdzie wciąż stanowią istotną formę realizacji wolności słowa, ściśle zresztą związanej z wolnością zgromadzeń (Czarny, Naleziński 1998, 7-8). Pozwalają wywierać wpływ na bieg spraw publicznych i w związku z tym mogą być uznane za formę urzeczywistniania konstytucyjnej zasady suwerenności narodu (Drab 2005, 238). Wolność zgromadzeń została zagwarantowana w art. 57 zd. 1 Konstytucji Rzeczypospolitej Polskiej z dnia 2 kwietnia 1997 r. (Dz.U. z 1997 r. Nr 78, poz. 483 ze zm.; dalej: Konstytucja RP). Zgodnie z tym przepisem każdemu zapewnia się wolność organizowania pokojowych zgromadzeń i uczestniczenia w nich. Gwarancje wolności pokojowego gromadzenia się zawierają także niektóre, ratyfikowane przez Rzeczpospolitą Polską, umowy międzynarodowe. W europejskim systemie ochrony praw człowieka można je odnaleźć w art. 11 Konwencji o Ochronie Praw Człowieka i Podstawowych Wolności sporządzonej w Rzymie dnia

${ }^{*}$ Uniwersytet Łódzki, Wydział Prawa i Administracji, Katedra Prawa Administracyjnego i Nauki Administracji, LKaminski@wpia.uni.lodz.pl. 
4 listopada 1950 r. (Dz.U. z 1993 r. Nr 61, poz. 284; dalej: Europejska Konwencja Praw Człowieka).

Wolność zgromadzeń nie jest ani nie może być absolutna. Jej ograniczenia są niezbędne z uwagi na ochronę praw i wolności innych osób oraz dla zabezpieczenia innych dóbr prawnie chronionych (Czarny, Naleziński 1998, 78-79). Problem kolizji praw jednostki dotyczy, rzecz jasna, nie tylko wolności zgromadzeń. Ogólnie można powiedzieć, że kolizja praw jednostki to taka sytuacja konfliktowa, która występuje, gdy różne podmioty mogą powoływać się na przysługujące im prawa lub wolności, co odróżnia ją od konkurencji praw jednostki, tj. sytuacji, gdy jeden podmiot może alternatywnie powoływać się na różne prawa bądź wolności, które mu w danym razie przysługują (Banaszak 1995, 69-70). Wolność zgromadzeń może wchodzić w kolizję z innymi prawami i wolnościami, w tym konstytucyjnie chronionymi, ale możliwa jest też kolizja wolności zgromadzeń przysługującej jednej grupie z wolnością zgromadzeń przysługującą grupie innej.

Kolizja pomiędzy wolnością zgromadzeń różnych grup może zaistnieć, gdy dwa lub więcej zgromadzenia odbywają się (lub też, zgodnie z zamierzeniem organizatorów, mają się odbyć) w tym samym miejscu i czasie ${ }^{1}$. Nie każda tego rodzaju sytuacja oznacza, że mamy do czynienia z kolizją wolności zgromadzeń służącej różnym podmiotom. Wszak w wielu wypadkach możliwe będzie odbycie więcej niż jednego zgrupowania w tym samym miejscu i czasie. Kolizja pomiędzy wolnością zgromadzeń różnych grup zachodzi wtedy, gdy nie jest możliwe spokojne odbycie wszystkich zamierzonych demonstracji. $\mathrm{Z}$ reguły z taką sytuacją mamy do czynienia wówczas, gdy uczestnicy kolidujących zgromadzeń są do siebie nastawieni antagonistycznie. A o to nietrudno, zwłaszcza gdy wziąć pod uwagę, że wydarzenia takie częstokroć służą artykułowaniu poglądów budzących spory i kontrowersje. To nie szczupłość dostępnej przestrzeni zatem, lecz nastawienie uczestników co najmniej jednego z kolidujących zgromadzeń zazwyczaj stoi na przeszkodzie ich wspólnemu i jednocześnie pokojowemu odbyciu się w tym samym miejscu i czasie. Rozważania w niniejszym opracowaniu koncentrują się wokół takich właśnie przypadków kolizji, gdy w rachubę wchodzi antagonistyczne nastawienie różnych grup. W praktyce to właśnie ten rodzaj kolizji wolności zgromadzeń różnych podmiotów może być źródłem zagrożeń dla bezpieczeństwa i porządku publicznego.

${ }^{1}$ Dla potrzeb dalszych rozważań za zgromadzenia odbywające się (czy też mające się odbyć) w tym samym miejscu i czasie będą uznawane również i takie zgromadzenia, które tylko częściowo nakładają się w wymiarze czasowym (np. jedno zgromadzenie ma się zacząć, gdy inne zgromadzenie, odbywające się w tym samym miejscu, będzie już w toku) lub przestrzennym (np. pikieta mająca się odbyć w pewnym punkcie trasy marszu, w czasie, gdy ów marsz będzie się tam znajdował). 


\section{ROZSTRZYGANIE KOLIZJI POMIĘDZY WOLNOŚCIĄ ZGROMADZEŃ RÓŻNYCH PODMIOTÓW W UJECCIU TEORETYCZNYM I W ŚWIETLE KONSTYTUCJI RP}

Rodzi się więc pytanie o sposób rozstrzygania kolizji pomiędzy wolnością zgromadzeń różnych grup. Podstawowa zasada ich rozstrzygania wynika już z samej Konstytucji RP, która w powołanym art. 57 poddaje ochronie wolność organizowania i uczestniczenia w zgromadzeniach o charakterze pokojowym. A contrario zgromadzenia, które takiego charakteru nie mają, nie podlegają konstytucyjnej ochronie. Pokojowego charakteru nie mają te demonstracje, których uczestnicy stosują przemoc fizyczną skierowaną przeciwko osobom lub rzeczom (np. budynkom) oraz takie, których uczestnicy nawołują w sposób jednoznaczny i bezpośredni do stosowania przemocy fizycznej (Czarny, Naleziński 2002, 581). Za pozbawione pokojowego charakteru należy też uznać zgromadzenie, które już w zamyśle swoich organizatorów ma mieć niepokojowy charakter w podanym wyżej rozumieniu (Wróbel 2002, 38). Zgrupowanie nie traci jednak pokojowego charakteru, jeżeli jego uczestnicy zostali zaatakowani przez członków innego zgromadzenia (czy też osoby postronne) i odpierają zamach, działając w granicach obrony koniecznej (Czarny, Naleziński 2002, 582; Wróbel 2002, 38), co zresztą można uzasadnić także poprzez odwołanie się do znanej paremii vim vi defendere omnes leges omniaque iura permittunt.

Reguła pierwszeństwa zgromadzeń pokojowych znajduje również potwierdzenie w orzecznictwie organów strasburskich. Za przykład może tu posłużyć chociażby wyrok Europejskiego Trybunału Praw Człowieka z dnia 21 czerwca 1988 r. w sprawie Plattform „Ärzte für das Leben” przeciwko Austrii (skarga nr 10126/82, LEX nr 81064). Na gruncie Europejskiej Konwencji Praw Człowieka prawo do kontrdemonstracji nie może być rozumiane tak szeroko, by w istocie niweczyło prawo do zgromadzania się (Nowicki 2002, 1224).

A zatem, niezależnie od przyjętego przez ustawodawcę modelu rozstrzygania kolizji między wolnością zgromadzeń różnych grup, konieczne jest przyznanie pierwszeństwa zgromadzeniom pokojowym przed tymi, które takiego charakteru nie mają. Gdy chodzi o rozstrzygnięcie kolizji między dwoma lub więcej pokojowymi zgromadzeniami, to z Konstytucji RP można wyinterpretować zasadę równości wszystkich zgromadzeń, skoro jej art. 32 głosi, że wszyscy są wobec prawa równi i wszyscy mają prawo do równego traktowania przez władze publiczne. Nie należy tu jednak zapominać, że art. 31 ust. 3 Konstytucji RP dopuszcza ograniczenia w zakresie korzystania z konstytucyjnych praw i wolności (a więc również wolności zgromadzeń), jeżeli są one ustanawiane w ustawie, nie naruszają istoty wolności i praw oraz są konieczne w demokratycznym państwie m.in. dla jego bezpieczeństwa lub porządku publicznego, a także dla ochrony wolności i praw innych osób. Ustawodawca może więc, pod pewnymi warunkami, przewidywać ograniczenia wolności zgromadzeń, 
w tym nakierowane na usuwanie kolizji pomiędzy dwoma lub więcej pokojowymi zgrupowaniami.

Zasadniczo ustawodawca może wybrać jeden z dwóch modeli rozstrzygania tego rodzaju kolizji pomiędzy wolnością zgromadzeń dwóch lub większej liczby podmiotów. Pierwszy model to równouprawnienie wszystkich pokojowych demonstracji. Nie oznacza on braku ustawowych ograniczeń wolności zgromadzeń, lecz przesłanką do ich stosowania nie będzie omawiana sytuacja kolizji praw podmiotowych. Ustawodawca takiej sytuacji bądź w ogóle nie dostrzega (jest ona prawnie indyferentna), bądź też wyposaża organy administracji publicznej jedynie w niewładcze środki oddziaływania, mające na celu uniknięcie kolizji różnych zgromadzeń (np. przekonywanie do kompromisowej zmiany miejsca lub czasu ich odbywania). Model ten sprzyja urzeczywistnieniu wolności zgromadzeń, ale za cenę ryzyka konfrontacji antagonistycznych grup, mogącej prowadzić do zagrożenia bezpieczeństwa i porządku publicznego, oraz narażenia na uszczerbek dóbr prawnie chronionych, takich jak życie czy zdrowie ludzkie.

Drugi możliwy model sprowadza się do przyznania organowi władzy publicznej kompetencji do władczego ingerowania w sferę wolności zgromadzeń w celu jednostronnego rozstrzygnięcia przez ten organ kolizji pomiędzy wolnością zgromadzeń różnych grup. Ustawodawca może tu przewidzieć takie środki, jak prewencyjny zakaz zgromadzenia, wyznaczenie innego miejsca lub czasu, czy też jego rozwiązanie, jeżeli już jest w toku. Tak jak wszystkie inne ograniczenia wolności pokojowego gromadzenia się, tak również i w tym przypadku ingerencja musi odpowiadać wymogom konstytucyjnym, w tym wynikającym z art. 31 ust. 3 Konstytucji RP. W szczególności oznacza to, że władcza ingerencja w tę sferę wolności, mająca na celu rozstrzygnięcie kolizji między pokojowymi demonstracjami, musi być niezbędna w celu ochrony wartości wskazanych w wymienionym przepisie Konstytucji RP, m.in. bezpieczeństwa i porządku publicznego oraz wolności i praw innych osób, bowiem to właśnie te wartości mogą być w pierwszym rzędzie narażone na uszczerbek w razie takiej kolizji. Ustawodawca zatem nie może przyznać organom stosującym prawo kompetencji do władczej ingerencji w każdym przypadku, gdy w tym samym miejscu i czasie mają się odbyć dwa zgromadzenia lub więcej. Ustawa musi nakładać na organ obowiązek zbadania, czy kolizja rzeczywiście zachodzi (np. zgrupowania mogą nie mieć antagonistycznego charakteru), czy nie da się jej usunąć przy pomocy środków niewładczych (np. przekonując organizatorów do korekty ich planów) i wreszcie, czy nie da się ochronić wartości konstytucyjnych poprzez zastosowanie takich środków władczych, które jednak nie zniweczą możliwości odbycia wszystkich kolidujących wydarzeń zgodnie z zasadniczym zamierzeniem organizatorów (np. oddzielenie dwóch zgromadzeń odbywających się na jednym placu za pomocą barierek). Regulacja ustawowa nieuwzględniająca tych wymogów powinna być uznana za niezgodną z zasadą adekwatności.

Z zasady tej wypływa jeszcze jeden istotny dla omawianej kwestii wniosek. Nieproporcjonalne byłoby zastosowanie władczej ingerencji wobec wszystkich 
pozostających w kolizji zgromadzeń, o ile mają one charakter pokojowy. W najprostszej sytuacji, jeżeli mamy do czynienia z dwoma antagonistycznymi zgrupowaniami mającymi się odbyć w tym samym miejscu i czasie, to wystarczające dla usunięcia takiej kolizji jest zastosowanie władczej ingerencji (np. zakazu) tylko wobec jednego z nich. Zakazanie obu trudno byłoby uznać za niezbędne dla ochrony wartości wskazanych w art. 31 ust. 3 Konstytucji RP, skoro to właśnie ich kolizja miałaby być przyczyną zagrożenia tych wartości. Sytuacja komplikuje się, gdy w jednym miejscu i czasie mają odbyć się więcej niż dwa zgromadzenia. Może się bowiem okazać, że np. z pięciu zaplanowanych w tym samym miejscu i czasie jedno jest demonstracją w określonej sprawie, trzy to kontrdemonstracje przeciwników tej sprawy (tyle że mające różnych organizatorów), zaś ostatnie ma dotyczyć zupełnie innej kwestii. Zasadniczo więc można powiedzieć, że ustawodawca powinien pozostawić organom stosującym prawo możliwość dostosowywania ingerencji do konkretnej sytuacji zbiegu miejsca i czasu wielu zgromadzeń tak, by w każdym przypadku ingerować w zakres wolności gromadzenia się tylko w niezbędnym zakresie.

Z powyższych rozważań można wyciągnąć wniosek, że skoro ingerowanie we wszystkie kolidujące zgrupowania byłoby konstytucyjnie niedopuszczalne, jako niespełniające wymogu niezbędności w demokratycznym państwie, to ustawodawca będzie musiał stworzyć reguły określające, na czyją korzyść rozstrzygać takie kolizje. W oparciu o normy Konstytucji RP trudno jest wskazać wymogi co do kryteriów takiego rozstrzygnięcia poza wspomnianą już zasadą bezwzględnego pierwszeństwa zgromadzeń pokojowych w razie ich kolizji z niepokojowymi. Ta reguła ma jednak największe znaczenie przy ocenie konstytucyjności środków nadzoru bieżącego nad zgromadzeniami. Problemem jest tu przede wszystkim odpowiednie ukształtowanie środków nadzoru prewencyjnego. W przypadku kolizji wolności zgromadzeń częstokroć łatwo będzie wykazać istotne ryzyko konfrontacji dwóch antagonistycznych grup, ale trudno będzie określić ex ante, czy i która spośród zaplanowanych demonstracji nie będzie miała charakteru pokojowego. Trzeba tu też wziąć pod uwagę, że konfrontacja między zgromadzeniami może, ale nie musi, oznaczać utratę pokojowego charakteru któregokolwiek z nich. Może polegać np. na zablokowaniu trasy przemarszu. Ponadto w doktrynie zwraca się też uwagę na to, że jeżeli aktów przemocy dopuszcza się tylko niewielka grupa uczestników, wówczas zgromadzenie in toto nie traci charakteru pokojowego, o ile takie zachowania nie spotykają się z akceptacją pozostałych uczestników (Czarny, Naleziński 2002, 582). W gruncie rzeczy kolizja między zgromadzeniem pokojowym a niepokojowym nie ma charakteru rzeczywistej kolizji praw podmiotowych, bowiem te pozbawione pokojowego charakteru nie korzystają z konstytucyjnej ochrony. Organy władzy publicznej będą uprawnione, a nawet obowiązane, do interwencji w przypadku, gdy zgromadzenie nie ma pokojowego charakteru i to niezależnie od tego, czy pozostaje ono w kolizji z jakimś innym zgrupowaniem. 


\section{ROZSTRZYGANIE KOLIZJI POMIĘDZY WOLNOŚCIĄ ZGROMADZEŃ RÓŻNYCH PODMIOTÓW W USTAWODAWSTWIE POLSKIM}

Pierwsza po 1989 r. administracyjnoprawna regulacja zgromadzeń, tj. nieobowiązująca już ustawa z dnia 5 lipca 1990 r. - Prawo o zgromadzeniach (tekst jedn. Dz.U. z 2013 r., poz. 397), opierała się na modelu równouprawnienia zgromadzeń. Ustawodawca nie przewidział bowiem jakichkolwiek mechanizmów rozstrzygania kolizji pomiędzy wolnością zgromadzeń różnych podmiotów. Wprawdzie zgodnie $\mathrm{z}$ art. 8 pkt 2 tej ustawy właściwy organ miał obowiązek zakazać zgromadzenia publicznego, jeżeli jego odbycie mogłoby zagrażać życiu lub zdrowiu ludzi albo mieniu w znacznych rozmiarach, ale podstawą zakazu mogła być tylko taka sytuacja, gdy zagrożenie pochodziłoby ze strony samego zgromadzenia, a nie kontrdemonstrantów. Taki wniosek znalazł potwierdzenie w orzecznictwie sądowym, m.in. w wyroku Naczelnego Sądu Administracyjnego z dnia 25 maja 2006 r. (I OSK 329/06, ONSAiWSA 2007/2/45). Analogiczne rozumowanie mogłoby być również przeprowadzone w odniesieniu do samej kontrdemonstracji, bo i ona wszakże jest zgromadzeniem, któremu przysługuje konstytucyjna ochrona, o ile ma charakter pokojowy. W praktyce prowadziło to do sytuacji, w której, mimo oczywistego, istotnego ryzyka starć między dwoma zgrupowaniami, organ administracji publicznej w wielu wypadkach nie mógł żadnego z nich zakazać, bowiem nie można byłoby dowieść, które z nich stanowiłoby źródło zagrożeń. Procedurę pozwalającą na usuwanie kolizji zgromadzeń w sytuacji, gdy w tym samym miejscu i czasie miało odbyć się więcej niż jedno zgromadzenie publiczne, wprowadzono do powołanej ustawy z 1990 r. dopiero po przeszło dwudziestu latach jej obowiązywania. Procedura wprowadzona na mocy przepisów ustawy z dnia 14 września 2012 r. o zmianie ustawy - Prawo o zgromadzeniach (Dz.U. z 2012 r., poz. 1115) obowiązywała jednak przez krótki czas, bowiem stosunkowo szybko stała się przedmiotem postępowania przed Trybunałem Konstytucyjnym, zakończonego wyrokiem z dnia 18 września 2014 r. (K 44/12, OTK-A 2014/8/92). Trybunał stwierdził częściową niekonstytucyjność przepisów nowej procedury rozwiązywania kolizji zgromadzeń. Skutkiem tego orzeczenia była praktyczna niemożność jej zastosowania (Kamiński 2016, 618).

Obecnie obowiązująca ustawa z dnia 24 lipca 2015 r. - Prawo o zgromadzeniach (tekst jedn. Dz.U. z 2018 r., poz. 408; dalej: Prawo o zgromadzeniach) częściowo urzeczywistnia model równouprawnienia zgromadzeń w sytuacji ich kolizji, a częściowo opiera się na modelu władczego rozstrzygania takich sytuacji konfliktowych, z zastosowaniem zróżnicowanych kryteriów. Przyjęcie mieszanego modelu wynika z daleko idącej dyferencjacji przedmiotowej zgromadzeń na gruncie nowego Prawa o zgromadzeniach. Ustawodawca wyróżnił cztery ich kategorie: organizowane na zasadach ogólnych (rozdz. 2 omawianej ustawy), organizowane w trybie uproszczonym (rozdz. 3), cykliczne (rozdz. 3a) oraz 
spontaniczne (rozdz. 4). Zróżnicowanie modelu postępowania w razie kolizji zgromadzeń można po części uzasadnić różnorodnym trybem ich organizowania. I tak zgrupowania organizowane na podstawie przepisów rozdz. 2 i 3 Prawa o zgromadzeniach wymagają uprzedniego zgłoszenia właściwemu organowi (stosownie do treści art. 7 ust. 1 oraz, odpowiednio, art. 22 ust. 1 omawianej ustawy), podczas gdy zgromadzenia cykliczne wymagają uzyskania zgody (zgodnie z art. 26a ust. 1 Prawa o zgromadzeniach). Z kolei zgromadzenia spontaniczne w ogóle nie są objęte nadzorem prewencyjnym.

Zważywszy, że dane zgromadzenie może pozostawać w kolizji z drugim, należącym do tej samej lub innej kategorii, można wyróżnić dziesięć ogólnych przypadków kolizji na gruncie Prawa o zgromadzeniach. Rzecz jasna dotyczy to tylko najprostszego wariantu, to jest sytuacji kolizji dwóch zgromadzeń. Kolizje większej liczby można jednak analizować poprzez pryzmat owych dziesięciu przypadków kolizji dwóch tylko zgrupowań.

Najbardziej rozbudowana jest procedura rozstrzygania kolizji zgromadzeń organizowanych na zasadach ogólnych. Zasady usuwania takich kolizji określa art. 12 ust. 1 Prawa o zgromadzeniach. Przepis ten przewiduje, że jeżeli wniesiono zawiadomienia o zamiarze zorganizowania dwóch lub większej liczby zgromadzeń, które mają się odbyć chociażby częściowo w tym samym miejscu i czasie, w szczególności w odległości mniejszej niż 100 m, i nie jest możliwe odbycie ich w taki sposób, aby ich przebieg nie zagrażał życiu lub zdrowiu ludzi albo mieniu w znacznych rozmiarach, o pierwszeństwie wyboru miejsca i czasu decyduje kolejność wniesienia zawiadomień, a w przypadku, gdy wniesione zawiadomienie nie spełniało wymagań określonych w art. 10, o kolejności wniesienia tego zawiadomienia decyduje data, godzina i minuta jego ponownego wniesienia, o ile tak wniesione zawiadomienie spełnia te wymagania. O rozstrzyganiu kolizji między dwoma zgromadzeniami, organizowanymi według przepisów rozdz. 2 Prawa o zgromadzeniach, przesądza więc zasada prior tempore, potior iure. W powołanym wyroku z dnia 18 września 2014 r. (K 44/12, OTK-A 2014/8/92) Trybunał Konstytucyjny wypowiedział się pozytywnie o możliwości przyjęcia reguły pierwszeństwa czasowego zgłoszenia jako zasady rozstrzygania kolizji zgromadzeń. Trzeba przy tym odnotować, że władcze rozstrzyganie kolizji zgromadzeń organizowanych na zasadach ogólnych to jedyny przypadek, gdy ustawodawca zdecydował się przyjąć tę regułę.

Samo rozstrzygnięcie kolizji zgromadzeń, organizowanych na podstawie rozdz. 2 Prawa o zgromadzeniach, może nastąpić na dwa sposoby. Pierwszy polega na wezwaniu organizatorów demonstracji, którym nie przysługuje pierwszeństwo do zmiany swoich zamierzeń. Podstawą prawną jest w tym wypadku art. 12 ust. 2 Prawa o zgromadzeniach, w myśl którego właściwy organ niezwłocznie wzywa, telefonicznie i za pomocą środków komunikacji elektronicznej, do zmiany miejsca lub czasu zgromadzeń tych spośród organizatorów, którym nie przysługuje pierwszeństwo wyboru miejsca i czasu. W doktrynie trafnie podnosi się, że dokonując 
wezwania organ nie może wskazywać alternatywnego miejsca bądź czasu odbycia demonstracji (Gajewski 2017, 83). Wypada jednak nie zgodzić się z innym, formułowanym w piśmiennictwie wnioskiem, że wezwanie, o którym mowa, jest czynnością materialno-techniczną (Gajewski 2017, 86). Wydaje się, że nosi ono wszelkie cechy aktu administracyjnego. Jest to bowiem czynność prawna, stanowiąca władcze rozstrzygnięcie konkretnej sprawy indywidualnie określonego podmiotu, usytuowanego w sferze zewnętrznej względem organu administrującego, który to rozstrzygnięcie podejmuje (na podstawie przepisów prawa powszechnie obowiązującego). Istotą tej czynności jest rozstrzygnięcie kolizji zgromadzeń poprzez wskazanie tych spośród konkurencyjnych zgrupowań, którym nie przysługuje pierwszeństwo wyboru czasu i miejsca.

Drugi sposób rozstrzygania omawianej kolizji to sui generis procedura negocjacyjna (a w pewnych wypadkach nawet koncyliacyjna), którą ustawodawca, nieco myląco, określa mianem rozprawy administracyjnej. Ma ona charakter fakultatywny, a więc wybór tej metody należy do obszaru władzy dyskrecjonalnej właściwego organu (tj. organu gminy). Zgodnie bowiem z art. 13 ust. 1 omawianej ustawy w przypadku kolizji zgromadzeń, o którym mowa w art. 12 ust. 1, organ gminy może przeprowadzić rozprawę administracyjną, jeżeli usprawni to uzgodnienie zmiany miejsca lub czasu zgromadzeń. Sięgnięcie po ten tryb powinno być uzasadnione zasadą ekonomii procesowej. Organ gminy niezwłocznie, nie później jednak niż 120 godzin przed planowaną datą zgromadzenia, telefonicznie i za pomocą środków komunikacji elektronicznej wzywa organizatorów zgromadzeń do uczestnictwa w rozprawie administracyjnej, przy czym niestawienie się organizatora zgromadzenia na rozprawę nie wstrzymuje jej przebiegu (art. 13 ust. 2). Określenie omawianej procedury przez ustawodawcę jako rozprawy administracyjnej wydaje się nietrafne, jej celem bowiem nie jest władcze rozstrzygnięcie kolizji zgromadzeń. Czynności, które podejmuje organ gminy na tej rozprawie, mają charakter niewładczy i można je uznać za szczególną formę działalności społeczno-organizatorskiej. Sensem rozprawy jest przekonanie organizatorów do znalezienia kompromisowego rozwiązania tego swoistego sporu, w jakim pozostają. Organ gminy może tu wystąpić w charakterze urzędowego koncyliatora, albowiem art. 13 ust. 3 Prawa o zgromadzeniach przewiduje, że organizatorom, którzy uczestniczą w rozprawie administracyjnej, organ gminy może przedstawić propozycję zmiany miejsca lub czasu zgromadzenia. Propozycja ta jest niewiążąca, a jej przedstawienie przez organ fakultatywne, ale wydaje się, że podjęcie się przez organ (skoro już zdecydował się zorganizować rozprawę) funkcji koncyliatora jest ze wszech miar pożądane. W myśl art. 13 ust. 4 natomiast, jeżeli na rozprawie administracyjnej organizatorzy zgromadzeń nie uzgodnią miejsca lub czasu tychże w taki sposób, aby ich przebieg nie zagrażał życiu lub zdrowiu ludzi albo mieniu w znacznych rozmiarach, dokonują oni wyboru miejsca lub czasu zgromadzeń zgodnie z kolejnością wniesienia zawiadomień o zamiarze zorganizowania zgromadzenia, spełniających wymagania 
określone w art. 10. Przepis ten stanowi niejako rozwinięcie reguły z art. 12 ust. 2 Prawa o zgromadzeniach.

Jeżeli omówiona wyżej procedura rozstrzygania kolizji zgromadzeń zakończy się fiaskiem, tj. organizatorzy nie dokonają korekty swoich zamierzeń stosownie do postanowień art. 12 ust. 2 bądź art. 13 Prawa o zgromadzeniach, ustawodawca przewidział obowiązek rozstrzygnięcia kolizji poprzez wydanie stosownego zakazu lub zakazów. Art. 14 pkt 2 Prawa o zgromadzeniach przewiduje bowiem, że organ gminy wydaje decyzję o zakazie zgromadzenia nie później niż 96 godzin przed planowaną datą zgromadzenia, jeżeli jego odbycie może zagrażać życiu lub zdrowiu ludzi albo mieniu w znacznych rozmiarach, w tym, gdy zagrożenia tego nie udało się usunąć w przypadkach, o których mowa w art. 12 lub art. 13. Zakaz zgromadzenia stanowi ultima ratio. Co oczywiste, zakaz powinien dotyczyć tych zgrupowań, którym nie przysługuje w danej sytuacji pierwszeństwo czasowe.

Jeszcze na gruncie poprzedniej, obecnie już nieobowiązującej, regulacji odbywania zgromadzeń Ryszard Szałowski wyraził pogląd, że ,,wezwanie organizatora do zmiany czasu, miejsca zgromadzenia, bądź trasy przejścia uczestników odnosi się do istoty wolności zgromadzeń" (Szałowski 2013, 123), a co za tym idzie - możliwość dokonania wspomnianego wezwania, a następnie wydania zakazu zgromadzenia jako sankcji niezastosowania się do niego przez organizatora uznał autor za niezgodne z art. 31 ust. 3 Konstytucji RP (Szałowski 2013, 123). A zatem ówcześnie obowiązująca regulacja, zdaniem Szałowskiego, ,godzi w istotę wolności zgromadzeń" (Szałowski 2013, 128). Pogląd ten wydaje się jednak zbyt daleko idący. Wprawdzie konieczność zmiany miejsca lub czasu zgromadzenia utrudnia jego zorganizowanie, a niekiedy może też utrudniać realizację celu zamierzonego przez organizatora, w tym osłabiać siłę oddziaływania zgromadzenia na opinię publiczną, ale przecież nie wyłącza możliwości jego odbycia się (o ile organizator zastosuje się do wezwania). Nie pozbawia też organizatora swobody wyboru miejsca i czasu, a jedynie ją ogranicza. Istota wolności zgromadzeń nie jest więc przez to ograniczenie naruszona. Procedura rozstrzygania kolizji zgromadzeń, wprowadzona w 2012 r. (do której odnosiły się wymienione uwagi Szałowskiego), nie była wolna od wad i rzeczywiście okazała się częściowo niekonstytucyjna, ale nie $\mathrm{z}$ powodu naruszenia istoty tej wolności.

Pozostałe przypadki władczego rozstrzygania kolizji zgromadzeń opierają się na zasadzie pierwszeństwa zgromadzenia określonego rodzaju. Tak jest w sytuacji kolizji zgromadzenia organizowanego na zasadach ogólnych ze zgromadzeniem cyklicznym. Regułę pierwszeństwa zgromadzenia cyklicznego ustawodawca wyraził wprost w art. 12 ust. 1 zd. 3 Prawa o zgromadzeniach, który stanowi, że zgromadzeniom takim przysługuje pierwszeństwo wyboru miejsca i czasu ich zorganizowania. Uzupełnieniem tej reguły jest obowiązek wydania zakazu zgromadzenia kolidującego ze zgromadzeniem cyklicznym na podstawie art. 14 pkt 3 tej ustawy. Przepis ten przewiduje, że organ gminy wydaje decyzję o zakazie nie później niż 96 godzin przed planowaną datą tego wydarzenia, jeżeli ma się odbyć w miejscu 
i czasie, w których odbywają się zgromadzenia organizowane cyklicznie. Należy przyjąć, że w przypadku takiego rodzaju kolizji nie znajdą zastosowania art. 12 ust. 2 i art. 13 Prawa o zgromadzeniach. Jest tak dlatego, że art. 14 pkt 3, w odróżnieniu od pktu 2 tego przepisu, nie wskazuje wyczerpania procedury przewidzianej w art. 12 lub art. 13 jako przesłanki wydania zakazu. Przesłanką jest jedynie tożsamość miejsca i czasu odbywania zgromadzeń. Brak jest też zresztą przesłanki zagrożenia życia i zdrowia ludzkiego lub mienia w znacznych rozmiarach, co stanowi warunek zastosowania procedur określonych $\mathrm{w}$ art. $12 \mathrm{i}$ art. 13 (a następnie ewentualnego zakazu zgromadzenia na podstawie art. 14 pkt 2).

Zasada pierwszeństwa zgrupowania określonego rodzaju znajdzie także zastosowanie w przypadku kolizji zgromadzenia spontanicznego ze zgromadzeniem innego typu. Zgodnie bowiem z art. 27 Prawa o zgromadzeniach uczestnicy zgromadzenia spontanicznego nie mogą zakłócać przebiegu zgromadzenia organizowanego w trybie przepisów rozdziału 2, 3 lub 3a. Rozwinięciem tej reguły jest art. 28 ust. 1 pkt 5 Prawa o zgromadzeniach, w myśl którego zgromadzenie spontaniczne może być rozwiązane przez funkcjonariusza kierującego działaniami Policji, jeżeli zakłóca przebieg zgromadzenia organizowanego $\mathrm{w}$ trybie przepisów rozdziału 2, 3 lub 3a. Środek stosowany przez administrację w celu usunięcia kolizji zgromadzeń ma więc $\mathrm{w}$ tym przypadku charakter środka nadzoru bieżącego, a nie prewencyjnego, co wynika z faktu, że zgromadzenia spontaniczne nie wymagają zawiadomienia. Pojęcie zakłócania zgromadzenia innego rodzaju przez zgromadzenie spontaniczne należy rozumieć jako wszelkie przejawy kolizji zgromadzeń, niekoniecznie przyjmujące postać zachowań agresywnych. Może to być np. bierne blokowanie trasy przemarszu.

W pozostałych pięciu przypadkach kolizji ustawodawca przyjął zasadę równouprawnienia wszystkich zgromadzeń. Innymi słowy brak jest władczych środków pozwalających na definitywne rozstrzyganie tychże kolizji. Z taką sytuacją mamy do czynienia w przypadku kolizji zgromadzenia organizowanego $\mathrm{w}$ trybie uproszczonym ze wszystkimi innymi zgromadzeniami z wyjątkiem jego kolizji ze zgromadzeniem spontanicznym. Ustawodawca nie przewidział bowiem możliwości wydania prewencyjnego zakazu takiego zgrupowania, a przesłanki jego rozwiązania (określone w art. 25 ust. 1 Prawa o zgromadzeniach) nie odwołują się do sytuacji kolizji tego zgromadzenia z innymi zgrupowaniami. Ze specyficzną sytuacją mamy jednak do czynienia w przypadku kolizji dwóch zgromadzeń organizowanych $\mathrm{w}$ trybie uproszczonym. Zgodnie $\mathrm{z}$ art. 26 Prawa o zgromadzeniach do tych zgromadzeń stosuje się odpowiednio m.in. art. 12 i art. 13 tej ustawy. A to oznacza, że w odniesieniu do kolizji dwóch zgromadzeń, organizowanych w oparciu o przepisy rozdz. 3 omawianej ustawy, znajdzie odpowiednie zastosowanie opisana wyżej procedura rozstrzygania kolizji zgromadzeń organizowanych na zasadach ogólnych, z tym że bez możliwości wydania zakazu zgromadzenia. Prowadzi to do wniosku, iż procedura może się zakończyć bez definitywnego rozstrzygnięcia kolizji. Właściwy organ będzie bowiem zobowiązany do wezwania 
organizatorów, którym nie przysługuje pierwszeństwo (według reguły czasowej) do zmiany miejsca lub czasu ich zgromadzeń (art. 12 ust. 2 w zw. z art. 26). Wezwanie nie będzie się jednak wiązało z możliwością wydania zakazu w razie uchybienia obowiązkowi zmiany miejsca i czasu przez zobligowanych do tego organizatorów. Mogą oni zatem je zignorować bez ponoszenia negatywnych konsekwencji prawnych.

Zasada równouprawnienia znajduje także zastosowanie w przypadku kolizji dwóch zgromadzeń spontanicznych i dwóch zgromadzeń cyklicznych. W tym drugim przypadku można jednak postulować de lege lata, żeby organ wydający zgodę na zgromadzenie cykliczne (tj. wojewoda) brał pod uwagę jego ewentualne kolizje z innym zgrupowaniem tego rodzaju, na które zgoda została już udzielona. Ustawodawca nie wskazuje bowiem w art. 26b ust. 1 Prawa o zgromadzeniach przesłanek wydania zgody na cykliczne organizowanie zgromadzeń w sposób enumeratywny, a jedynie przykładowy. To daje wojewodzie możliwość uwzględniania również innych okoliczności w ramach zakresu przyznanej mu w tym przypadku władzy dyskrecjonalnej. Zasadne wydaje się więc, żeby wojewoda brał pod uwagę również unikanie kolizji dwóch zgromadzeń cyklicznych.

\section{WNIOSKI KOŃCOWE}

Kolizja zgromadzeń stanowi co najmniej potencjalne zagrożenie dla bezpieczeństwa i porządku publicznego, dlatego ustawodawca zdecydował się na interwencję w niektórych wypadkach jej zaistnienia. Warto tu jednak przypomnieć, że w wyroku z dnia 10 stycznia 2014 r. (I OSK 2538/13, LEX nr 1456989) Naczelny Sąd Administracyjny wyraził pogląd, że ochrona bezpieczeństwa i porządku publicznego oraz wolność zgromadzeń to wartości równorzędne. Nie można więc przyjąć, że w każdym przypadku wolność ta winna ustąpić przed wartością, jaką jest bezpieczeństwo i porządek publiczny. W granicach wyznaczonych przez Konstytucję RP oraz wiążące Rzeczpospolitą Polską unormowania prawnomiędzynarodowe ustawodawca może dokonać wyboru spośród wielu dopuszczalnych sposobów radzenia sobie z kolizją pomiędzy wolnością zgromadzeń przysługującą różnym grupom. $Z$ punktu widzenia ochrony bezpieczeństwa i porządku publicznego najbardziej uzasadnione wydaje się wprowadzenie mechanizmów władczego rozstrzygania takich kolizji przez władze publiczne i to najlepiej ex ante. $\mathrm{Z}$ perspektywy ochrony wolności zgromadzeń natomiast najbardziej odpowiedni wydaje się model równouprawnienia wszystkich pokojowych zgrupowań. W obecnym Prawie o zgromadzeniach mamy do czynienia z mozaiką rozwiązań, a wybór tych szczegółowych po części jest uzasadniony specyfiką określonych kategorii zgromadzeń, co przede wszystkim dotyczy zgromadzeń spontanicznych. W pewnej mierze jest jednak arbitralny, a nawet niespójny. Trudno przekonująco uzasadnić, czemu tak dalece różny jest sposób potraktowania kolizji zgromadzeń 
organizowanych na zasadach ogólnych w porównaniu z kolizją zgromadzeń organizowanych w trybie uproszczonym. W przypadku tych drugich ustawodawca odsyła do odpowiedniego stosowania procedury usuwania kolizji zgromadzeń organizowanych na zasadach ogólnych, ale bez możliwości wydania zakazu. Rozwiązanie to można chyba określić jako lex imperfecta. Dotyczy to zwłaszcza odesłania do odpowiedniego stosowania art. 12 ust. 2. Przewidziane w tym przepisie wezwanie do zmiany miejsca i czasu jest w odniesieniu do zgromadzeń organizowanych na podstawie rozdz. 3 działaniem w gruncie rzeczy pozornym, nakłada bowiem obowiązek niepodparty jakąkolwiek sankcją.

Niezrozumiałe są też przyczyny dyferencjacji przesłanek zastosowania władczych środków w celu rozstrzygnięcia kolizji zgromadzeń. W sytuacji kolizji zgromadzenia spontanicznego ze zgromadzeniem innego typu przesłanką jest zakłócanie innego zgromadzenia, ale już w przypadku kolizji zgromadzeń regulowanych w rozdz. 2 Prawa o zgromadzeniach będzie to węższa przesłanka zagrożenia dla życia i zdrowia ludzkiego albo mienia w znacznych rozmiarach. Procedura usuwania kolizji zgromadzeń zatem, przewidziana w art. 12, art. 13 i art. 14 pkt 2 Prawa o zgromadzeniach, nie obejmuje wszystkich sytuacji, a jedynie kolizje kwalifikowane. Większe wątpliwości budzi jednak sposób rozstrzygania kolizji między zgromadzeniem organizowanym na zasadach ogólnych a zgromadzeniem cyklicznym. Podstawą do wydania zakazu zgrupowania organizowanego na podstawie rozdz. 2 omawianej ustawy jest tu bowiem sama czasowa lub przestrzenna zbieżność tegoż ze zgromadzeniem cyklicznym. Jednakże nie każda taka zbieżność oznaczać będzie, że mamy do czynienia z kolizją praw podmiotowych. W danym przypadku zgrupowania mogą nie mieć antagonistycznego, czy nawet konkurencyjnego, charakteru. Może tu więc dochodzić do nieproporcjonalnej ingerencji w wolność pokojowych demonstracji.

\section{BIBLIOGRAFIA}

Banaszak, Bogusław. 1995. Prawa jednostki i systemy ich ochrony. Wrocław: Kolonia Limited.

Czarny, Piotr, Bogumił Naleziński. 1998. Wolność zgromadzeń. Warszawa: Wydawnictwo Sejmowe.

Czarny, Piotr, Bogumił Naleziński. 2002. „Wolność zgromadzeń”. W Prawa i wolności obywatelskie w Konstytucji RP. Red. Bogusław Banaszak, Artur Preisner. 569-587. Warszawa: Wydawnictwo C.H. Beck.

Drab, Mirella Katarzyna. 2005. „Wolność zgromadzeń jako jeden z instrumentów realizacji zasady suwerenności Narodu". W Koncepcje suwerenności. Zbiór studiów. Red. Izabela Gawłowicz, Iwona Wierzchowiecka. 238-247. Warszawa: LexisNexis.

Gajewski, Sebastian. 2017. „Art. 12”. W Prawo o zgromadzeniach. Komentarz. Red. Sebastian Gajewski, Aleksander Jakubowski. 82-86. Warszawa: Wydawnictwo C.H. Beck.

Kamiński, Łukasz. 2016. „Administracja samorządowa wobec zgromadzeń. Węzłowe problemy administracyjnoprawnego nadzoru nad zgromadzeniami w dwudziestopięciolecie funkcjonowania samorządu terytorialnego". W Prawne problemy samorzadu terytorialnego z perspek- 
tywy 25-lecia jego funkcjonowania. Red. Barbara Jaworska-Dębska, Rafał Budzisz. 605-622. Warszawa: Wydawnictwo C.H. Beck.

Nowicki, Marek Antoni. 2002. Europejski Trybunał Praw Człowieka. Orzecznictwo. T. 2: Prawo do życia i inne prawa. Kraków: Zakamycze.

Szałowski, Ryszard. 2013. „O zakazie zgromadzenia publicznego zgłoszonego później”. W Jednostka wobec władczej ingerencji administracji publicznej. T. 1. Red. Ewa Wójcicka. 121-129. Częstochowa: Wydawnictwo im. S. Podobińskiego Akademii im. Jana Długosza w Częstochowie.

Wróbel, Andrzej. 2002. „Wolność zgromadzania się”. W Wolności i prawa polityczne. Red. Marek Chmaj, Wiesław Skrzydło. 9-49. Kraków: Zakamycze.

\section{Akty prawne}

Konstytucja Rzeczypospolitej Polskiej z dnia 2 kwietnia 1997 r. (Dz.U. z 1997 r. Nr 78, poz. 483 ze zm.).

Konwencja o Ochronie Praw Człowieka i Podstawowych Wolności sporządzona w Rzymie dnia 4 listopada 1950 r. (Dz.U. z 1993 r. Nr 61, poz. 284).

Ustawa z dnia 5 lipca 1990 r. - Prawo o zgromadzeniach (tekst jedn. Dz.U. z 2013 r., poz. 397).

Ustawa z dnia 14 września 2012 r. o zmianie ustawy - Prawo o zgromadzeniach (Dz.U. z 2012 r., poz. 1115).

Ustawa z dnia 24 lipca 2015 r. - Prawo o zgromadzeniach (tekst jedn. Dz.U. z 2018 r., poz. 408).

\section{Orzecznictwo}

Wyrok Europejskiego Trybunału Praw Człowieka z dnia 21 czerwca 1988 r., skarga nr 10126/82, LEX nr 81064.

Wyrok Naczelnego Sądu Administracyjnego z dnia 25 maja 2006 r., sygn. akt I OSK 329/06, ONSAiWSA 2007/2/45.

Wyrok Naczelnego Sądu Administracyjnego z dnia 10 stycznia 2014 r., sygn. akt I OSK 2538/13, LEX nr 1456989.

Wyrok Trybunału Konstytucyjnego z dnia 18 września 2014 r., sygn. akt K 44/12, OTK-A 2014/8/92.

\section{Łukasz Kamiński}

\section{CONFLICT OF FREEDOM OF ASSEMBLY BETWEEN DIFFERENT ENTITIES AND THE MEANS OF RESOLVING IT}

\footnotetext{
Abstract. The conflict of freedom of assembly between different groups occurs when two or more antagonistic assemblies are supposed to be held at the same place and time. Two model solutions of handling the conflict of assemblies are possible: the model of equal treatment of all assemblies and the model of the authoritatively resolving of the conflict by the means of restricting the freedom of assembly. Both these model solutions are acceptable on the grounds of the Constitution of Poland. Neither of them is fully adopted in the Polish legislation. Under the Polish legislation, some conflicts can be resolved in an authoritative manner based on varied criteria. The applied regulations seem to be incoherent and inconsistent in some cases and inadequate in one particular case.

Keywords: assemblies, freedom of assembly, conflict of rights, administrative law, public order and safety.
} 